\title{
ILMU HUKUM: HAKEKAT KEILMUANNYA DITINJAU DARI SUDUT FILSAFAT ILMU DAN TEORI ILMU HUKUM
}

\author{
Titik Triwulan Tutik ${ }^{1}$
}

\begin{abstract}
This paper examines the nature of science of jurisprudence regarding the terms of the philosophy of science and legal theory. From the point of philosophy, the term science bears two meanings, as a product and as a process. As a product, science is refer to 'knowledge' that has been provided truth in a particular field and are arranged in a system. In the perspective of some legal theories, law as science has a distinctive character (suigeneris), that it is normative. Those characteristics caused some law scholars that do not understand the characteristics of jurisprudence have doubted law as a science. Doubt it caused more normative jurisprudence rather than empirical and his study object with respect to the guidance of behavior in a way that compliance is not entirely dependent on free will is concerned, but can be imposed by a public authority. Science still accepted as a science of law while respecting the character of law which constitute the personality of law. Thus the study of jurisprudence should be moved from the scientific nature of the law, which includes two (2) aspects of the approach, namely: the approach from the point of philosophy of science, and the approach from the standpoint of legal theory.
\end{abstract}

Keywords: the nature of science, sui generis, jurisprudence, philosophy of science, theory of law

\begin{abstract}
Abstrak
Tulisan ini mengkaji mengenai hakekat keilmuan ilmu hukum ditinjau dari sudut filsafat ilmu dan teori hukum. Dari sudut filsafat, istilah ilmu [science] menyandang dua makna, yaitu sebagai produk dan sebagai proses. Sebagai produk, ilmu adalah pengetahuan yang sudah terkaji kebenarannya dalam bidang tertentu dan tersusun dalam suatu sistem. Teori hukum memandang, bahwa ilmu hukum memiliki karakter yang khas (suigeneris), yaitu sifatnya yang normatif. Ciri yang demikian menyebabkan sementara kalangan yang tidak memahami karakteristik ilmu hukum meragukan hakekat keilmuan hukum. Keraguan itu disebabkan karena ilmu hukum lebih bersifat normatif ketimbang empiris dan obyek telaahnya berkenaan dengan tuntunan perilaku dengan cara tertentu yang kepatuhannya tidak sepenuhnya bergantung pada kehendak bebas yang bersangkutan, melainkan dapat dipaksakan oleh kekuasaan publik. Ilmu hukum tetap diterima sebagai ilmu dengan tetap menghormati karakter ilmu hukum yang merupakan kepribadian ilmu hukum. Dengan
\end{abstract}

\footnotetext{
${ }^{1}$ Dosen Fakultas Syari'ah IAIN Sunan Ampel Surabaya, Alumni Program Doktor Ilmu Hukum Program Pascasarjana Universitas`Airlangga. Alama korespondensi: e-mail: tt_titik@yahoo.com.
} 
demikian pengkajian ilmu hukum harus beranjak dari hakikat keilmuan hukum, yang meliputi 2 (dua) aspek pendekatan, yaitu: pendekatan dari sudut falsafah ilmu, dan pendekatan dari sudut pandang teori hukum.

Kata kunci: hakekat ilmu, sui generis, ilmu hukum, filsafat ilmu, teori ilmu hukum

\section{Pendahuluan}

Ilmu hukum dalam perkembangannya, selalu diperdebatkan keabsahannya sebagai ilmu, baik oleh ilmuwan bidang sosial maupun ilmuwan yang berkecimpung di bidang hukum sendiri. Sudah sejak lama sebuah pertanyaan timbul dan harus dijawab secara akademis, apakah Ilmu Hukum itu ilmu? Menurut Lasiyo, pertanyaan tersebut seyogyanya tidak sekedar dicari jawabnya secara instan, tetapi harus dikaji dan dianalisis berdasarkan landasan pijak yang kuat dan jelas dari aspek keilmuan. ${ }^{2}$

Dari segi kajian penelitian, ilmu hukum pada dasarnya bukanlah untuk melakukan verifikasi atau menguji hipotesis sebagaimana penelitian ilmu sosial maupun penelitian ilmu alamiah. Di dalam penelitian hukum tidak dikenal istilah data. Metode kajian terhadap ilmu hukum beranjak dari sifat dan karakter ilmu hukum itu sendiri. Menurut Philipus M. Hadjon, ilmu hukum memiliki karakter yang khas, yaitu sifatnya yang normatif, praktis, dan preskriptif. Karakter yang demikian menyebabkan sementara kalangan yang tidak memahami karakteristik ilmu hukum itu mulai meragukan hakekat keilmuan hukum. Keraguan tersebut dikarenakan karena kajian terhadap ilmu hukum lebih bersifat ketimbang empiris. ${ }^{3}$

Berdasarkan paparan tersebut, isu hukum yang muncul adalah: Pertama, apakah Ilmu Hukum merupakan ilmu? Jika ilmu hukum adalah ilmu, termasuk dalam cabang ilmu manakah ilmu hukum? Kedua, apakah sama karakter ilmu hukum dan metode kajian ilmu hukum dengan ilmu lainnya misalnya ilmu alam atau ilmu sosial? Dari dua isu hukum tersebut, maka tulisan ini disusun mengikuti sistematika antara lain: (I) Pendahuluan; (II) Konstruksi Ilmu Hukum; (III) Karakter Normatif Ilmu Hukum; (IV) Jenis dan Lapisan Ilmu Hukum; (V) Penerapan Hukum dan Pembentukan Hukum (Praktek Hukum); dan (VI) Penutup.

${ }^{2}$ Lasiyo dalam M. Hadin Muhjad, dkk., "Peran Filsafat Ilmu dalam Ilmu Hukum: Kajian Teoritis dan Praktis”, (Surabaya: Unesa University Press, 2003), hal. iii.

${ }^{3}$ Philipus M. Hadjon dan Tatiek Sri Djatmiati, "Argumentasi Hukum", (Yogyakarta, Gadjah Mada University Press, 2005), hal. 1. 


\section{Konstruksi Ilmu Hukum}

Istilah ilmu [science] menyandang dua makna, yaitu sebagai produk dan sebagai proses. Sebagai produk, ilmu adalah pengetahuan yang sudah terkaji kebenarannya dalam bidang tertentu dan tersusun dalam suatu sistem. Wim van Dooren, mengemukakan bahwa ilmu dapat didefinisikan sebagai pengetahuan yang sah secara intersubyektif dalam bidang kenyataan tertentu yang bertumpu pada satu atau lebih titik tolak dan ditata secara sistematis. ${ }^{4}$ Sebagai proses, istilah ilmu menunjuk pada kegiatan akal budi manusia untuk memperoleh pengetahuan dalam bidang tertentu secara bertatanan (stelselmatig) atau sistematis dengan menggunakan seperangkat pengertian yang secara khusus diciptakan untuk itu, untuk mengamati dan megamati gejala-gejala [gegevens] yang relevan pada bidang tersebut, yang hasilnya berupa putusan-putusan yang keberlakuannya terbuka untuk dikaji oleh orang lain berdasarkan kriteria yang sama dan sudah disepakati atau yang dilazimkan dalam lingkungan komunitas keahlian dalam bidang yang bersangkutan.

Berangkat dalam dua makna tersebut, C.A. van Peursen, mendefinsikan bahwa ilmu adalah sebuah kebijakan. Ilmu adalah sebuah strategi ${ }^{5}$ untuk memperoleh pengetahuan yang dapat dipercaya tentang kenyataan, yang dijalankan orang terhadap [yang berkenaan] kenyataannya. ${ }^{6}$

Sementara itu, keberadaan ilmu dalam pandangan Harold Berman, harus memenuhi tiga perangkat kriteria, yaitu: (1) kriteria metodologikal, dalam peristilahan metodologi, ilmu dalam arti modern, merupakan seperangkat pengetahuan yang terintegrasi yang lahir dalam konteksitas dedukto-hipotetiko-verifikatif; (2) kriteria nilai, yaitu subtansi yang mengacu pada premis-premis nilai obyektivitas, bebas pamrih [disinterestedness], skeptis, toleransi, dan keterbukaan; (3) kriteria sosiologikal, yang meliputi pembentukan kominitas ilmuwan, penautan berbagai disiplin ilmiah, dan status sosial. ${ }^{7}$ Dengan demikian keberadaan ilmu merujuk pada suatu struktur yang unsur-unsurnya meliputi; (1) pra-anggapan sebagai guiding principle; (2) bangunan sistematis yakni: metode dan subtansi [konsep dan teori]; (3) keberlakuan intersubyektif; dan (4) tanggungjawab etis. ${ }^{8}$

\footnotetext{
${ }^{4}$ Pada definisi ini tampil 3 (tiga) aspek penting, yaitu titik tolak, bangunan sistematis dan keberlakuan subsubyektif. Lihat Bernard Arief Sidharta, "Refleksi Tentang Struktur Ilmu Hukum", (Bandung: Mandar Maju, 2000), hal. 104.

${ }^{5}$ Merujuk pada cara kerja metodis-sistematis dengan bersaranakan seperangkat lambang dalam pengelolaan dan penjelasan gejala-gejala terberi serta penataan gejala-gejala tersebut ke dalam sebuah sistem

${ }^{6}$ Lihat Bernard Arif Sidharta, Op. Cit.

${ }^{7}$ Ibid., hal. 105.

${ }^{8}$ Titik Triwulan Tutik, "Pengantar Ilmu Hukum”, (Jakarta: Prestasi Pustaka, 2006), hal. 2. Lihat juga, Trianto dan Titik Triwulan Tutik, "Ilmu Hukum sebagai Sui Generis: Sebuah
} 
Berdasarkan ciri-ciri ilmu di atas, maka terdapat berbagai cara untuk mengklasifikasi ilmu-ilmu ke dalam beberapa kelompok dan sub-kelompok, tergantung pada aspek [patokan/kriteria] yang digunakan. Berdasarkan aspek substansi, dikenal Ilmu Formal dan Ilmu Empiris.

Ilmu formal merujuk pada ilmu yang tidak bertumpu pada pengalaman atau fakta empiris. Obyek kajiannya bertumpu pada pada struktur murni yaitu analisis aturan operasional dan struktur logika. Dapat disebutkan yang termasuk dalam ilmu formal misalnya, logika dan matematika serta teori sistem.

Ilmu empiris merujuk kepada ilmu yang bertumpu pada pengetahuan faktual. Dalam rangka memperoleh pengetahuan faktual itu dieksplorasilah kenyataan aktual. Ilmu yang berkarakteristik demikian bersumber pada empiris [pengalaman] dan eksperimen sehingga bersifat empirikal dan eksperimental. Ilmu empiris dalam mengelola dan menganalisis pengetahuan faktualnya sering mempergunakan perspektif positivis, sehingga sering disebut juga sebagai ilmu positif - walaupun tidak sepenuhnya benar. Ilmu empiris terdiri dari ilmu-ilmu alam [naturwissen-schaften] dan ilmu-ilmu manusia [geisteswissenscaften].

Ilmu formal dan ilmu empiris merupakan genus dari kelompok ilmu teoritis, yaitu ilmu yang ditujukan untuk memperoleh pengetahuan saja dengan mengubah dan/atau menambah pengetahuan. Adapun sebagai vis a vis ilmu teoritis adalah ilmu praktis, yaitu ilmu yang mempelajari aktivitas aktivitas penerapan itu sendiri sebagai obyeknya, selain itu juga bertujuan untuk mengubah keadaan, atau menwarkan penyelesaian terhadap masalah konkret. Ilmu praktis dapat dibagi dalam dua kelompok besar yaitu ilmu praktis nomologis dan ilmu praktis normologis. Ilmu praktis normologis berusaha memperoleh pengetahuan faktual-empiris, yaitu pengetahuan tentang hubungan ajeg yang ceteris paribus berdasarkan asas kausalitas-deterministik. Sedangkan ilmu praktis nomologis berusaha menemukan hubungan antara dua hal atau lebih berdasarkan asas imputasi [menautkan tanggungjawab/kewajiban] untuk menetapkan apa yang seharusnya menjadi kewajiban subyek tertentu dalam situasi konkret, namun dalam kenyataannya apa yang seharusnya terjadi itu tidak niscaya dengan sendirinya terjadi. Ilmu Praktis Normologis disebut juga dengan Ilmu Normatif atau Ilmu Dogmatik.

Merujuk pada klasifikasi keilmuan di atas, maka apakah ilmu hukum adalah ilmu? Menjawab pertanyaan ini secara arif, Philipus M. Hadjon mengatakan, bahwa bukan masanya untuk memperdebatkan hal tersebut. Ilmu hukum diterima sebagai ilmu dengan tetap menghormati karakter ilmu hukum yang merupakan kepribadian ilmu hukum. ${ }^{9}$ Apa yang kemukakan Philipus M. Hadjon tersebut cukuplah beralasan, karena apabila ditinjau dari sudut pandang karakteristik dan kepribadian, Ilmu Hukum dipandang sebagai suatu ilmu

Pengantar", dalam Trianto dan Titik Triwulan Tutik (eds.), "Bunga Rampai Ilmu Hukum”, (Jakarta: Prestasi Pustaka, 2007), hal. vii.

${ }^{9}$ Philipus M. Hadjon, Pengkajian Ilmu Hukum Dogmatik (Normatif), dalam "Yuridika", Jurnal Hukum Universitas Airlangga Surabaya, No. 6 Tahun IX, November - Desember 1994, hal. 1 . 
memiliki karakter yang khas. Dengan karakter demikian ilmu hukum merupakan ilmu tersendiri (sui generis). ${ }^{10}$ Sehingga dengan kualitas keilmiahannya sulit dikelompokkan dalam salah satu cabang pohon ilmu, baik cabang ilmu pengetahuan alam, cabang ilmu pengetahuan sosial, maupun cabang ilmu humaniora. Tetapi berdasarkan karakteristik keilmuwan, menurut Bernard Arief Sidharta, ${ }^{11}$ ilmu hukum termasuk dalam kelompok ilmu praktis, walaupun demikian sebagaimana ilmu kedokteran, ilmu hukum menempati kedudukan istimewa dalam klasifikasi ilmu, bukan karena mempunyai sejarah yang panjang, tetapi juga karena sifatnya sebagai ilmu normatif dan dampak langsungnya terhadap kehidupan manusia dan masyarakat yang terbawa oleh oleh sifat dan problematikanya.

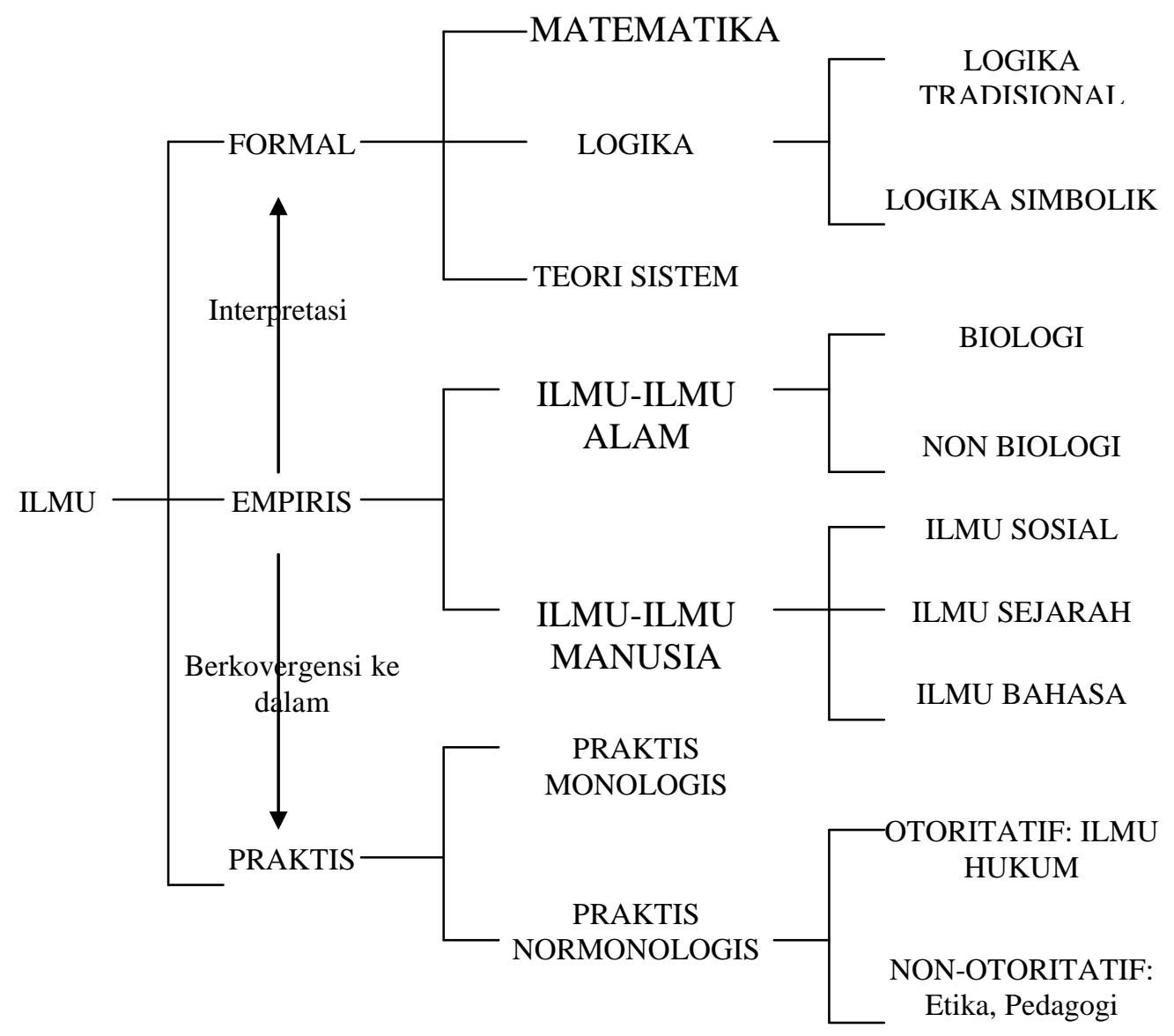

Gambar 1. Ragam Cabang Ilmu (Sumber: Bernard Arief Sidharta, 2000: 114)

${ }^{10}$ Ibid.

${ }^{11}$ Bernard Arif Sidharta, Op. Cit., hal. 113. 


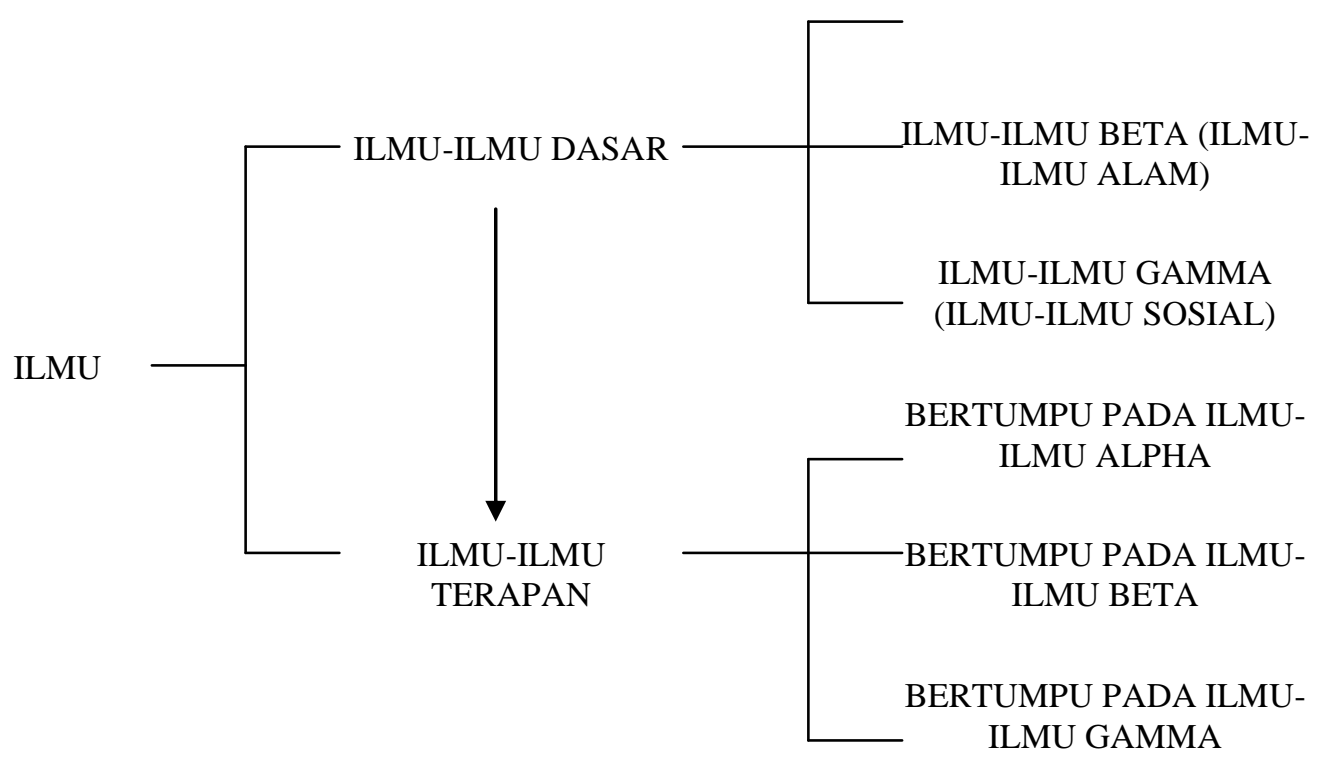

Gambar 2. Ragam Cabang Ilmu (Sumber: Bernard Arief Sidharta, 2000: 114)

\section{Karakter Normatif Ilmu Hukum}

\section{Terminologi Ilmu Hukum}

Ilmu Hukum memiliki berbagai istilah, rechtswetenschap atau rechtstheorie dalam bahasa Belanda, jurisprudence atau legal science [Inggris], dan jurisprudent [Jerman]. Dalam kepustakaan Indonesia tidak tajam dalam penggunaan istilah. Istilah ilmu hukum di Indonesia disejajarkan dengan istilah-istilah dalam bahasa asing tersebut. Misalnya, istilah Rechwetenschap oleh Jan Gijssels dan Mark van Hoecke diterjemahkan dalam bahasa Inggris sebagai Jurisprudence. Apabila diterjemahkan secara harfiah Rechwetenschap berarti Science of Law. Istilah itu dihindari karena istilah science dapat diidentikkan dengan kajian yang bersifat empiris. Kenyataannya, hukum adalah kajian yang lebih bersifat normatif ${ }^{12}$.

Istilah rechtswetenschap [Belanda] dalam arti sempit adalah dogmatika hukum atau ajaran hukum [de rechtsleer] yang tugasnya adalah deskripsi hukum positif, sistematisasi hukum posisitf dan dalam hal tertentu juga eksplanasi. Dengan demikian dogmatika hukum tidak bebas nilai tetapi sarat dengan nilai. Rechtswetenschap dalam arti luas meliputi: dogmatika hukum, teori hukum [dalam arti sempit] dan filsafat hukum.

12 Peter Mahmud Marzuki, "Penelitian Hukum", (Jakarta: Kencana Prenada Media Group, 2005), hal. 20. 
Rechtstheorie juga mengandung makna sempit dan luas. Dalam arti sempit rechtstheorie adalah lapisan ilmu hukum yang berada di antara dogmatika hukum dan filsafat hukum. Teori hukum dalam arti ini merupakan ilmu eksplanasi hukum [een verklarende wetenschap van het recht].

Istilah jurispudence, legal science, dan legal philosophy dalam bahasa Inggris, mempunyai makna yang berbeda dengan istilah-istilah Belanda di atas. Lord Lloyd O Hamstead dan M.D.A. Freeman ${ }^{14}$ memberikan gambaran sebagai berikut:

Jurisprudence involves the study of general theoretical questions about the nature of laws and legal system, about the relationship of law to justice and morality and about the social nature of law ... and science, however, is concerned with empirically observable fact and events.

HPH Visser Thooft, dari sudut pandang filsafat ilmu, menggunakan istilah rechtswetenschappen [ilmu-ilmu hukum], dan merumuskan sebagai disiplin yang obyeknya hukum. Atas dasar itu dikatakan: recht is made wetwnschap. ${ }^{15}$ Sementara Meuwissen, menggunakan istilah rechtsbeoefening [pengembanan hukum] untuk menunjuk pada semua kegiatan manusia berkenaan dengan adanya dan berlakunya hukum di dalam masyarakat. ${ }^{16}$

\section{Karakter Normatif Ilmu Hukum}

Sebagaimana telah dibahas di atas, bahwa ilmu hukum memiliki karakter yang khas, yaitu sifatnya yang normatif. Ciri yang demikian menyebabkan sementara kalangan yang tidak memahami kepribadian ilmu hukum itu dan meragukan hakekat keilmuan hukum. Keraguan itu disebabkan karena dengan sifat yang normatif ilmu hukum bukanlah ilmu

13 Teori hukum [rechtstheorie] dalam konteks ini merupakan ilmu yang sifatnya interdisipliner yang dalam arti luas digunakan dalam rechtswetenschap arti yang sama dengan dalam arti luas J. Gijssels dan Marck van Hoecke dalam Philipus M. Hadjon dan dan Tatiek Sri Djamiati, Op. Cit., h. 6

${ }^{14}$ Ibid.

${ }^{15}$ Ibid.

${ }^{16}$ Pengertian pengembanan hukum dibedakan ke dalam Pengembanan Hukum Praktis dan Pengembanan Hukum Teoritis. Pengembanan Hukum Praktis adalah semua kegiatan manusia berkenaan dengan hal mewujdukan hukum dalam kenyataan kehidupan sehari-hari secara konkret, sedangkan Pengembanan Hukum Teoritis menunjuk pada pada refleksi teoritis terhadap hukum, yaitu kegiatan akal budi untuk memeproleh penguasaan intelektual atau pemahaman hukum secara ilmiah atau secara metodis sistematis-logis-rasional. Lihat, Bernard Arief Sidharta, Op. Cit., h. 117 
empiris. ${ }^{17}$ Selain itu juga obyek telaahnya berkenaan dengan tuntunan perilaku dengan cara tertentu yang kepatuhannya tidak sepenuhnya bergantung pada kehendak bebas yang bersangkutan, melainkan dapat dipaksakan oleh kekuasaan publik. ${ }^{18}$

Memang harus diakui bahwa di sisi lain juris Indonesia berusaha mengangkat derajat keilmuan hukum dengan mengembangkan aspek empiris dari ilmu hukum melalui kajian-kajian yang bersifat empirikal. ${ }^{19}$ Usaha menghidupkan aspek empiric dari ilmu hukum diantaranya dilakukan dengan menerapkan metode-metode penelitian sosial dalam kajian hukum selain tetap mempergunakan kajian normatif itu sendiri. ${ }^{20}$ Langkah ini dilakukan antara lain dengan merumuskan format-format penelitian hukum selain dengan membedah peraturan (produk hukum) dari aspek substansinya, juga dengan membedah aspek empirisnya dengan dibantu metode penelitian yang dipinjam dari metode penelitian ilmu sosial [penelitian empirik]. ${ }^{21}$

Menetapkan metode penelitian hukum dalam cakupan yang lebih luas [pengkajian ilmu hukum], seharusnya beranjak dari hakekat keilmuan hukum. Ada dua pendekatan yang dapat dilakukan untuk menjelaskan keilmuan hukum dan dengan sendirinya membawa konsekuensi pada metode kajiannya. Pertama, pendekatan dari sudut falsafah ilmu. Kedua, pendekatan dari sudut pandang teori hukum.

\section{Pendekatan dari Sudut Falsafah Ilmu}

Filsafat ilmu lahir sebagai refleksi secara filsafati akan hakikat ilmu yang tidak mengenal titik henti dalam menuju sasaran yang hendak dicapai yaitu kebenaran hakiki dan kenyataan riil $^{22}$. Hal ini sesuai dengan tujuan dari Filsafat Ilmu yang menurut Lasiyo adalah menguasai hakikat

${ }^{17}$ Philipus M. Hadjon dan Tatiek Sri Djamiati, Op. Cit., hal. 1.

${ }^{18}$ Bernard Arif Sidharta, Op. Cit.

${ }^{19}$ Dalam sudut pandang Philipus M. Hadjon dan Tatiek Sri Djamiati, hal ini merupakan salah satu sebab terjadinya berbagai kerancuan dalam usaha pengembangan ilmu hukum [seolah-olah ilmu hukum termasuk cabang ilmu social - padangan ini adalah kaparah]. Melalui kajian ini sebagian juris Indonesia menjadi kehilangan kepribadian dan konsekuensi. Alhasil, pembangunan hukum melalui pembentukan hukum tidak dapat tertangani secara professional pendidikan hukum tidak jelas arahnya. Lihat, Ibid., hal. 1-2.

${ }^{20}$ Metode sosial dapat digunakan dalam fundamental research yang memandang hukum sebagai fenomena sosial. Lihat, Terry Hutchinson dalam Ibid., hal. 2.

21 Lihat Banakar dan Travers, 2011. Catatan ini ditambahkan pada tulisan untuk memperlihatkan sudut pandang yang bersifat menyeluruh tentang apa yang dimaksud dengan penelitian hukum. Tidak hanya dari satu perspektif saja. -Editor

${ }^{22}$ Sri Winarsi, Hukum Otonomi Saerah dalam Perspektif Filsafat Ilmum, dalam "Jurnal Konstitusi”, LKK Universitas Airlangga Volume I Nomor 1, November 2008, hal. 94. 
ilmu dalam konteks metodologi dan implementasinya dalam kehidupan manusia. $^{23}$

Berdasarkan pendapat tersebut, peranan falsafah ilmu dalam pengembangan ilmu pengetahuan, membedakan ilmu dari 2 (dua) sudut pandangan, yaitu pandangan positivistik yang melahirkan ilmu empiris dan pandangan normatif yang melahirkan ilmu normatif atau dogmatika hukum. Bagaimana sekarang dengan Ilmu Hukum dari sudut pandang filsafat ilmu?

Menurut Philipus M. Hadjon, bahwa dari sudut ini ilmu hukum memiliki 2 (dua) sisi tersebut. Pada satu sisi ilmu hukum dengan karakter aslinya sebagai ilmu normatif dan pada sisi lain ilmu hukum memiliki segi-segi empiris. Sisi empiris tersebut yang menjadi kajian ilmu hukum empiris seperti sociological jurisprudence, dan socio legal jurisprudence. Dengan demikian dari sudut pandang ini, ilmu hukum normatif metode kajiannya khas. Ilmu hukum empiris dapat dikaji melalui penelitian kuantitatif atau kualitatif, tergantung sifat datanya ${ }^{24}$.

Hakekat keilmuan ilmu hukum apabila ditinjau dari pendekatan falsafah ilmu, dapat digambarkan sebagai berikut:

1. Pandangan positivisme ... Ilmu Empiris

- sociological jurisprudence

- socio legal jurisprudence

Ilmu hukum empiris

- penelitian kualitatif-kuantitatif

(the gab is described but is rarely explained)

2. Pandangan normatif

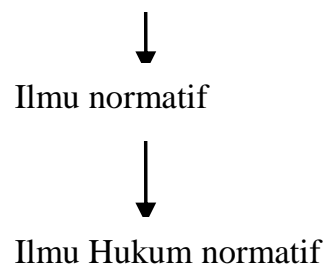

Gbr. 3. Pendekatan Falsafah Ilmu

\section{Pendekatan dari Sudut Pandang Teori Hukum}

Dari sudut pandang teori hukum, ilmu hukum dibagi atas tiga lapisan utama, yaitu dogmatik hukum, teori hukum [dalam arti sempit], dan

${ }^{23}$ Lasiyo, "Filsafat Ilmu Pengetahuan", Handout, Sekolah Pascasarjana Universitas Gadjah Mada Yogyakarta, hal. 2.

${ }^{24}$ Philipus M. Hadjon, Op. Cit., hal. 2. 
filsafat hukum. Ketiga lapisan tersebut pada akhirnya memberi dukungan pada praktek hukum, yang masing-masing mempunyai karakter yang khas dengan sendirinya juga memiliki metode yang khas. Persoalan tentang metode dalam ilmu hukum merupakan bidang kajian teori hukum [dalam arti sempit]. Dengan pendekatan yang obyektif seperti tersebut di atas dapatlah ditetapkan metode mana yang paling tepat dalam pengkajian ilmu hukum.

\begin{tabular}{|c|c|c|c|c|}
\hline $\begin{array}{c}\text { Dogmatik } \\
\text { Hıkım }\end{array}$ & $\begin{array}{c}\text { Sejarah } \\
\text { Hıkım }\end{array}$ & $\begin{array}{c}\text { Perbandingan } \\
\text { Hıkım }\end{array}$ & $\begin{array}{c}\text { Sosiologi } \\
\text { Hıkım }\end{array}$ & $\begin{array}{c}\text { Psikologi } \\
\text { Hıkım }\end{array}$ \\
\cline { 1 - 2 } Tlmu Hukum & \\
\hline Teori Hukum (dalam arti sempit) & \\
\hline
\end{tabular}

Gbr. 4. Lapisan Ilmu Hukum menurut Teori Ilmu Hukum (Sbr. Bernard Arief Sidharta, 2000: 162).

\section{Jenis Dan Lapisan Ilmu Hukum}

Ilmu hukum [dari segi obyek] dapat dibedakan atas ilmu hukum dalam arti sempit, yang dikenal dengan ilmu hukum dogmatik [ilmu hukum normatif] dan ilmu hukum dalam arti luas. Ilmu hukum dalam arti luas dapat ditelaah dari sudut pandangan sifat pandang ilmu maupun dari sudut pandangan tentang lapisan ilmu hukum seperti yang dilakukan oleh J. Gijssels dan Mark van Hoecke.

Dari sudut pandang ilmu dibedakan pandangan positivisme dan pandangan normatif. Dari sudut pandangan ini dibedakan ilmu hukum normatif [dogmatik] dan ilmu hukum empiris. Sifat keilmuan dapat dilihat dari tiga aspek, yaitu: proses, produk dan produsen [ilmuwan]. Perbedaan sifat keilmuan dua bidang ilmu hukum tersebut dapat digambarkan dalam skema berikut.

Tabel 1. Perbedaan Sifat Keilmuwan Bidang Ilmu Hukum

\begin{tabular}{|l|l|l|}
\cline { 2 - 3 } \multicolumn{1}{c|}{} & \multicolumn{1}{c|}{$\begin{array}{c}\text { Pandangan Positivistik: } \\
\text { Ilmu Hukum Empirik }\end{array}$} & $\begin{array}{c}\text { Pandangan Normatif: } \\
\text { Ilmu Hukum Normatif }\end{array}$ \\
\hline Relasi inti & Subyek-subyek & Subyek-subyek \\
\hline Jenis pengetahuan & Obyektif & Inter-subyektif \\
\hline Sikap ilmuwan & Pengamat/penonton & Peserta \\
\hline Perspektif & Eksternal & Internal \\
\hline
\end{tabular}




\begin{tabular}{|l|l|l|}
\hline Teori kebenaran & Teori korespondensi & Teori pragmatik \\
\hline Proposisi & Hanya informatif [empiris] & Normatif dan evaluatif \\
\hline Metode & $\begin{array}{l}\text { Hanya metode pengalaman } \\
\text { inderawi }\end{array}$ & Termasuk juga metode lain \\
\hline Moral & Non-kognitif & Kognitif \\
\hline Hubungan hukum-moral & Pemisahan tegas & Tidak ada pemisahan \\
\hline Ilmu & $\begin{array}{l}\text { Hanya sosiologi hukum } \\
\text { empiris da teori hukum } \\
\text { empiris }\end{array}$ & Ilmu hukum dalam arti luas \\
\hline
\end{tabular}

Sumber: J.J.H. Bruggink, 1999: 189.

Perbedaan antara ilmu hukum empiris dan ilmu hukum normatif menurut D.H.M. Meuwissen digambarkan dalam sifat ilmu hukum empiris, antara lain:

1) secara tegas membedakan fakta dan norma;

2) gejala hukum harus murni empiris, yaitu fakta sosial;

3) metode yang digunakan adalah metode ilmu empiris; dan

4) bebas nilai. $^{25}$

Implikasi dari perbedaan mendasar antara ilmu hukum normatif dan ilmu hukum empirik adalah: Pertama, dari hubungan dasar sikap ilmuwan. Dalam ilmu hukum empirik ilmuwan adalah sebagai penonton yang mengamati gejala-gejala obyeknya yang dapat ditangkap oleh pancaindra. Dalam ilmu hukum normatif, yuris secara aktif menganalisis norma sehingga peranan subyek sangat menonjol. Kedua, dari segi kebenaran ilmiah. Kebenaran ilmu hukum empirik adalah kebenaran korespondensi, yaitu bahwa sesuatu itu benar karena didukung fakta dengan dasar kebenaran pragmatik yang pada dasarnya adalah konsensus sejawat sekeahlian. Kebenaran ilmu hukum normatif karena yuris menganalisis norma dengan menggunakan perspektif keahliannya, maka bersifat subyektif. ${ }^{26}$

J. Gijssels dan Mark van Hoecke, membedakan ilmu hukum berdasarkan pelapisan ilmu hukum, yang meliputi filsafat hukum, teori hukum, dan dogmatik hukum ${ }^{27}$. Ketiga lapisan ilmu hukum tersebut

${ }^{25}$ Philipus M. Hadjon, Pengkajian Ilmu Hukum ..., Op. Cit., hal. 2.

${ }^{26}$ Catatan ini ditambahkan oleh editor karena penjelasan penulis tentang perbedaan persepsi terhadap kebenaran antara kajian hukum normatif dengan kajian hukum empiris belum selesai.

${ }^{27}$ Ibid., hal. 3. 
selanjutnya diarahkan kepada praktek hukum. Berikut ini dijelaskan mengenai masing-masing lapisan ilmu hukum tersebut.

\section{Filsafat Hukum}

Secara kronologis perkembangan ilmu hukum diawali oleh filsafat hukum dan disusul dogmatik hukum [ilmu hukum positif]. Perkembangan ini sejalan dengan pendapat Lili Rasjidi ${ }^{28}$, bahwa filsafat hukum adalah refleksi teoritis [intelektual] tentang hukum yang paling tua, dan dapat dikatakan merupakan induk dari semua refleksi teoritis tentang hukum.

Filsafat hukum adalah filsafat atau bagian dari filsafat yang mengarahkan refleksinya terhadap hukum atau gejala, sebagaimana dikemukakan J. Gejssels, ${ }^{29}$ filsafat hukum adalah filsafat umum yang diterapkan pada hukum dan gejala hukum. Hal yang sama juga dalam dalil D.H.M. Meuwissen, bahwa rechtfilosofie is filosofie. Filsafat hukum adalah filsafat karena di dalam kajian tersebut, orang merenungkan semua persoalan fundamental dan masalah-masalah perbatasan yang berkaitan dengan gejala hukum.

Berkaitan dengan ajaran filsafati dalam hukum, maka ruang lingkup filsafat hukum tidak lepas dari ajaran filsafat itu sendiri, yang meliputi:

1) ontologi hukum, yakni mempelajari hakekat hukum, misalnya hakekat demokrasi, hubungan hukum dan moral dan lainnya;

2) aksiologi hukum, yakni mempelajari isi dari nilai seperti; kebenaran, keadilan, kebebasan, kewajaran, penyalahgunaan wewenang dan lainnya;

3) ideologi hukum, yakni mempelajari rincian dari keseluruhan orang dan masyarakat yang dapat memberikan dasar atau legitimasi bagi keberadaan lembaga-lembaga hukum yang akan datang, sistem hukum atau bagian dari sistem hukum;

4) epistemologi hukum, yakni merupakan suatu studi meta filsafat. Mempelajari apa yang berhubungan dengan pertanyaan sejauh mana pengetahuan mengenai hakekat hukum atau masalah filsafat hukum yang fundamental lainnya yang umumnya memungkinkan;

5) teleologi hukum, yakni menentukan isi dan tujuan hukum;

6) keilmuan hukum, yakni merupakan meta teori bagi hukum; dan

7) logika hukum, yakni mengarah kepada argumentasi hukum, bangunan logis dari sistem hukum dan struktur sistem hukum. ${ }^{30}$

\footnotetext{
${ }^{28}$ Bernard Arief Sidharta, Op. Cit., hal. 119.

${ }^{29}$ Philipus M. Hadjon, Op. Cit., hal. 4.

${ }^{30}$ Ibid., hal. 4-5.
} 
Tabel 2. Sifat Keilmuan Filsafat Hukum

\begin{tabular}{|l|l|}
\cline { 2 - 2 } \multicolumn{1}{c|}{} & \multicolumn{1}{c|}{ Filsafat Hukum } \\
\hline Tujuan & Landasan dan batas-batas kaidah \\
hukum
\end{tabular}

Sumber: JJH Bruggink, 1999: 181.

\section{Teori Hukum [dalam arti sempit]}

Teori Hukum dalam lingkungan berbahasa Inggris, disebut dengan jurisprudence atau legal theory. Teori Hukum lahir sebagai kelanjutan atau pengganti allgemeine rechtslehre yang timbul pada abad ke-19 ketika minat pada filsafat hukum mengalami kelesuan karena dipandang terlalu abstrak, spekulatif dan dogmatis. Istilah Allgemeine rechtslehre ini mulai tergeser oleh istilah rechtstheorie yang diartikan sebagai teori dari hukum posisif yang mempelajari masalah-masalah umum yang sama pada pada semua sistem hukum. Adapun masalah-masalah umum tersebut meliputi: sifat, hubungan antara hukum dan negara serta hukum dan masyarakat.

Sehubungan dengan ruang lingkup dan fungsinya, teori hukum diartikan sebagai ilmu yang dalam perspektif interdisipliner dan eksternal secara kritis menganalisis berbagai aspek gejala hukum, baik dalam konsepsi teoritisnya maupun dalam kaitan keseluruhan, baik dalam konsepsi teoritis maupun manifestasi praktis. Tujuannya adalah untuk memperoleh pemahaman yang lebih baik dan memberikan penjelasan sejernih mungkin tentang bahan hukum yang tersaji dan kegiatan yuridis dalam kenyataan masyarakat. ${ }^{31}$

Teori hukum merupakan ilmu eksplanasi hukum yang sifatnya interdisipliner. Eksplanasi dalam teori hukum sifatnya eksplanasi analisis sedangkan dalam dogmatika hukum merupakan eksplanasi teknik yuridis dan dalam bidang filsafat sebagai eksplanasi reflektif.

Sifat interdisipliner dapat terjadi melalui dua cara: pertama, menggunakan hasil disiplin lain untuk eksplanasi hukum; kedua, dengan metode sendiri meneliti bidang-bidang seperti: sejarah hukum, sosiologi

${ }^{31}$ Bernard Arief Sidharta, Op. Cit., hal. 122. 
hukum dan lainnya. ${ }^{32}$ Permasalahan utama ialah apakah yuris mampu secara mandiri melakukan hal tersebut.

Berkaitan dengan sifat interdisipliner, maka bidang kajian teori hukum meliputi:

1) analisis bahan hukum, meliputi konsep hukum, norma hukum, sistem hukum, konsep hukum teknis, lembaga hukum-figur hukum, fungsi dan sumber hukum;

2) ajaran metode hukum, meliputi metode kajian dogmatik terhadap hukum, metode pembentukan hukum dan metode penerapan hukum;

3) metode keilmuan dogmatik hukum, yaitu apakah ilmu hukum sebagai disiplin logika, disiplin eksperimental atau disiplin hermenetik.

4) kritik ideologi hukum. Berbeda dengan ketiga bidang kajian di atas, kritik ideologi merupakan hal baru dalam bidang kajian teori hukum. Ideologi adalah keseluruhan nilai atau norma yang membangun visi orang terhadap manusia dan masyarakat. ${ }^{33}$

Tabel 3. Sifat Keilmuwan Teori Hukum

\begin{tabular}{|c|c|c|}
\hline & \\
\hline & \multicolumn{2}{|c|}{ Teori Hukum } \\
\hline & Empiris & Kontemplatif \\
\hline Obyek & \multicolumn{2}{|c|}{$\begin{array}{l}\text { 1. Gejala umum dalam hukum positif [algemene } \\
\text { rechtsleer] } \\
\text { 2. Kegiatan hukum: } \\
\text { - dogmatika hukum } \\
\text { - pembentukan hukum } \\
\text { - penemuan hukum }\end{array}$} \\
\hline Sasaran & \multicolumn{2}{|c|}{ Teoritis } \\
\hline Perspektif & Eksternal & Internal \\
\hline Teori kebenaran & Korespondensi & Pragmatis \\
\hline Proposisi & Informatif atau empiris & Normatif dan evaluatif \\
\hline
\end{tabular}

Sumber: J.J.H. Bruggink, 1999: 176.

\footnotetext{
${ }^{32}$ Philipus M. Hadjon, Op. Cit., hal. 3.

${ }^{33}$ Ibid., h. 4
} 


\section{Dogmatika Hukum}

Dogmatika hukum (atau kajian dogmatis terhadap hukum) merupakan ilmu hukum dalam arti sempit. Titik fokusnya adalah hukum positif. D.H.M. Meuwissen (1979), ${ }^{34}$ memberikan batasan pengertian dogmatika hukum sebagai memaparkan, menganalisis, mensistematisasi dan menginterpretasi hukum yang berlaku atau hukum positif.

Berbeda dengan apa yang dikemukakan oleh M. van Hoecke $(1982)^{35}$. Ia mendefinisikan dogmatika hukum sebagai cabang ilmu hukum [dalam arti luas] yang memaparkan dan mensistematisasi hukum positif yang berlaku dalam suatu masyarakat tertentu dan pada suatu waktu tertentu dari suatu sudut pandang normatif.

Berdasarkan definisi tersebut terlihat, tujuan ahli dogmatika hukum bekerja tidak hanya secara teoritikal, dengan memberikan pemahaman dalam sistem hukum, tetapi juga secara praktikal. Dengan kata lain, dogmatika hukum berkenaan dengan suatu masalah tertentu, menawarkan alternatif penyelesaian yuridik yang mungkin. Hal itu menyebabkan bahwa ahli dogmatika hukum bekerja dari sudut perspektif internal, yaitu menghendaki dan memposisikan diri sebagai partisipan yang ikut berbicara [peserta aktif secara langsung] dalam diskusi yuridik terhadap hukum posistif.

Dengan demikian dapat disimpulkan bahwa teori kebenaran yang paling sesuai bagi ahli dogmatika hukum adalah teori pragmatis. Proporsi yang ditemukan dalam dogmatika hukum bukan hanya informatif atau empirik, tetapi terutama yang normatif dan evaluatif.

Tabel 4. Hubungan Dogmatik Hukum dengan Teori Hukum

\begin{tabular}{|c|c|}
\hline Dogmatik Hukum & Teori Hukum \\
\hline $\begin{array}{l}\text { 1. mempelajari aturan hukum dari } \\
\text { segi teknis; }\end{array}$ & $\begin{array}{l}\text { 1. merupakan refleksi pada teknik } \\
\text { hukum; }\end{array}$ \\
\hline 2. berbicara tentang hukum; & $\begin{array}{l}\text { 2. tentang cara yuris bicara tentang } \\
\text { hukum }\end{array}$ \\
\hline 3. bicara hukum dari segi hukum & $\begin{array}{l}\text { 3. bicara hukum dari perspektif } \\
\text { yuridis ke dalam bahasa non } \\
\text { yuridis }\end{array}$ \\
\hline 4. bicara problem yang konkret & $\begin{array}{l}\text { 4. bicara tentang pemberian alasan } \\
\text { terhadap hal tersebut. }\end{array}$ \\
\hline
\end{tabular}
Sumber: Philipus M. Hadjon, 1994: 3.

${ }^{34}$ J.J.H. Bruggink, "Refleksi Tentang Hukum", Terjemahan Bernard Arief Sidharta, (Bandung: Citra Aditya Bhakti, 1999), hal. 169.

${ }^{35}$ Ibid. 
Berdasarkan tabel tersebut terlihat bahwa teori hukum tidaklah senantiasa normatif seperti dogmatika hukum. Teori hukum merupakan metateori bagi dogmatika hukum.

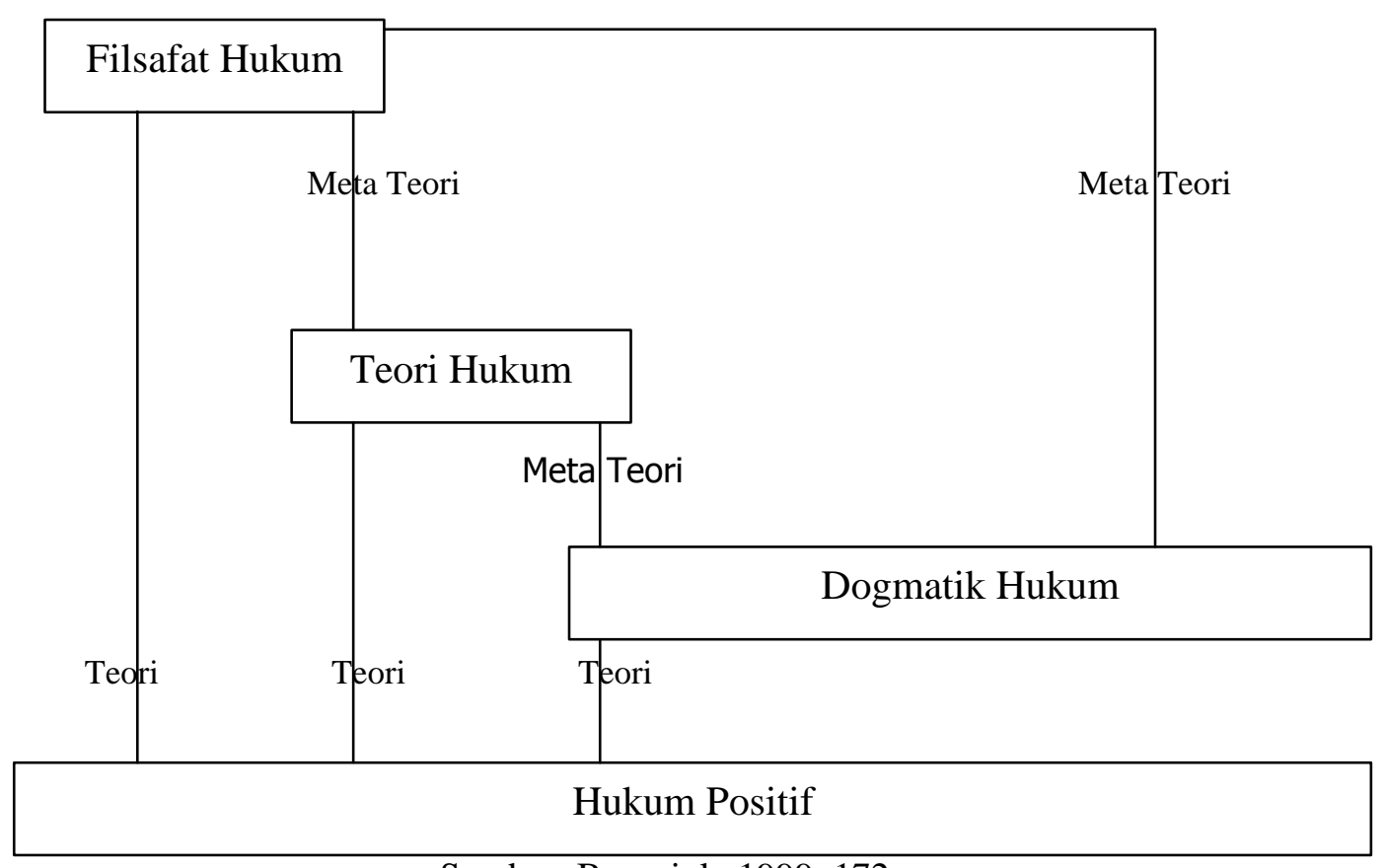

Sumber: Bruggink, 1999: 172.

Gambar 5. Hubungan Filsafat Hukum, Teori Hukum dan Dogmatik Hukum

\section{Praktek Hukum: Penerapan dan Pembentukan Hukum}

Ilmu hukum dipandang sebagai ilmu, baik dari sudut pandangan positivistik maupun sudut pandangan normatif. Dogmatika hukum, teori hukum, dan filsafat hukum pada akhirnya harus diarahkan kepada praktek hukum. Praktek hukum menyangkut 2 (dua) aspek utama, yaitu pembentukan hukum dan penerapan hukum.

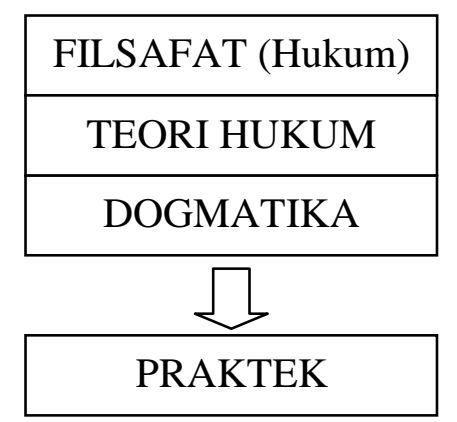

Gbr. 6. Alur Pengembangan Hukum 


\section{Penerapan Hukum}

Menerapkan hukum berarti memberlakukan peraturan yang sifatnya umum ke dalam suatu kasus yang sifatnya konkret. Dalam ungkapan klasik disebur De rechter is bounche de la loi, yang mengandung arti kiasan hakim adalah corong atau alat undang-undang. Hal ini melukiskan betapa beratnya tugas hakim yang harus mampu menangkap maksud pembuat undang-undang. Berdasarkan beban tugas hakim itu, peran penemuan hukum merupakan tugaas yang harus dilakukan dengan interpretasi besar dalam menentukan isi atau maksud hukum tertulis.

Roscoe Pound menjelaskan langkah penerapan hukum menjadi 3 [tiga] bagian, yaitu:

a. Menemukan hukum, artinya menetapkan pilihan di antara sekian banyak hukum yang sesuai dengan perkara yang akan diperiksa oleh hakim;

b. Menafsirkan kaidah hukum dari hukum yang telah dipilih sesuai dengan makna ketika kaidah itu dibentuk; dan

c. Menerapkan kaidah yang telah ditemukan dan ditafsirkan kepada perkara yang akan diputuskan oleh hakim. ${ }^{36}$

\section{Pembentukan Hukum}

Permasalahan penerapan hukum antara lain mengenai: interpretasi hukum, kekosongan hukum [leemten in het trecht], antinomi dan norma yang kabur [vage normen].

Interpretasi hukum lahir dari kesulitan hakim pada waktu memahami maksud pembuat undang-undang, ${ }^{37}$ selain itu dalam kaitannya dengan usaha menemukan hukum [rechtsvinding]. Artinya hukum harus ditemukan dan apabila tidak berhasil menemukan hukum tertulis, hukum harus dicari dari hukum yang hidup dalam masyarakat, yaitu berupa pembentukan hukum oleh hakim [rechtsvorming].

Arti penting interpretasi merujuk pada sarana untuk mengatur daya kelenturan peraturan perundang-undangan dapat pula terjadi pada hukum yang dibuat oleh pembuat perundang-undangan.

Philipus M. Hadjon, mengatakan bahwa metode interpretasi hukum meliputi: interpretasi gramatikal, interpretasi sistematis, wets-en rectshistorische interpretatie, interpretasi perbandingan hukum interpretasi perbandingan hukum, interpretasi antisipasi, dan interpretasi teleologis. ${ }^{38}$

${ }^{36}$ Soewoto, Metode Interpretasi Hukum Terhadap Konstitusi, dalam “Yuridika”, Jurnal Hukum Universiotas Airlangga Surabaya, No. 1 Tahun V, Januari - Pebruari 1990, hal. 32.

${ }^{37}$ Ibid., hal. 31.

${ }^{38}$ Philipus M. Hadjon, "Pengkajian Hukum ...., "Op. Cit., hal. 6. Bandingkan dengan metode interpretasi yang dikemukan Olberseh van Bemmelen dalam Soewoto, Ibid., hal. 35. 
Van Bemmelen dalam bukunya Praktische rechtsvragen (1891) membedakan metode interpretasi meliputi: (1) de textuale interpretatie, (2) intentionele interpretatie, (3) principiele interpretatie, (4) rationele interpretatie, (5) morele interpretatie, (6) comparatieve interpretatie, (7) analogische interpretatie, (8) legislative interpretatie, (9) historische interpretatie, dan (10) evolutieve interpretatie.

De textuale interpretatie merupakan nama baru saja dari interpretasi gramatikal. Intentionele interpretatie dijelaskan sebagai gericht op de bedoeling van de wet. Dengan begitu kedua jenis interpretasi ini sebenarnya tidak lain dari teleologische interpretatie. Adapun penafsiran prinsipil [principiele interpretatie] dan penafsiran atas normal hukum [morele interpretatir] merupakan jenis penafsiran baru oleh van Bemmelen. Penafsiran prinsipil adalah penafsiran yang gericht op strekking, doel, motieven of beginselen van de wet. Sedangkan interpretasi komparatif merupakan nama lain dari interpretasi sistematis.

\section{a. Interpretasi Gramatikal}

Interpretasi gramatikal mengartikan bahwa suatu term hukum suatu bagian kalimat menurut bahasa sehari-hari atau bahasa hukum. Dalam istilah Belanda sebagai "De rechter die zoekt naar de algemene of jurisch-technische betekenis van de woorden van de wet, hanteert de "gramaticale interpretatie" [methode]."

Menurut Sudikno Mertokusumo dan A. Pitlo, bahwa interpretasi gramatikal itu harus logis. Sebagai contoh penafsiran mengenai istilah "menggelapkan" yang secara implisit tercantum dalam Pasal 41 KUH Pidana ada kaitannya ditafsirkan sebagai menghilangkan ${ }^{39}$.Apabila dengan interpretasi gramatikal tersebut hakim tidak berhasil atau kurang puas, maka ia akan menggunakan interpretasi sistematis [systematische interpretatie].

\section{d. Interpretasi Sistematis}

Melalui metode ini hakim akan mendapatkan arti suatu pasal dalam dalam kaitannya dengan pasal-pasal yang lain. Undangundang atau pasal-pasal tertentu akan diberi makna dalam hubungannya dengan makna dari pasal-pasal terkait dalam suatu tatanan norma hukum yang berlaku. Dengan kata lain bahwa interpretasi sistematis bertitik tolak dari sistem aturan mengartikan sesuatu ketentuan hukum.

Menurut Menurut Sudikno Mertokusumo dan A. Pitlo, menafsirkan undang-undang tetap harus berada dalam koridor sistem perundang-undangan. Misalnya, jika hendak mengetahui tentang

39 Sudikno Mertokusumo dan A. Pitlo, "Bab-Bab Tentang Penemuan Hukum", (Bandung: Aditya Citra Bhakti, 1993), hal. 15. 
sifat pengakuan anak yang dilahirkan di luar perkawinan oleh orang tuanya, hakim dipersilakan mencari ketentuan-ketenuan dalam KUH Perdata dan menghubungkannya dengan Pasal 278 KUH Perdata ${ }^{40}$.

\section{e. Wets-en rectshistorische interpretatie}

Merujuk pada M. van Hoecke, ${ }^{41}$ menyebutkan ada dua macam penafsir histories, yaitu wetshistorische interpretatie, dan rechtshistorische interpretatie. Usaha menelusuri maksud pembentukan undang-undang adalah suatu wetshistorische interpretatie", misalnya dengan mempelajari "memorie penjelasan", menelusuri nasehat yang diberikan oleh "Raad van State" [baca DPA]. Dalam usaha menemukan jawaban atas suatu isu hukum dengan menelusuri perkembangan hukum (aturan) disebut "historische interpretatie". Misalnya jika hendak menjelaskan ketentuan dalam KUH Perdata - tidak terbatas pada sampai pada terbentuknya KUH Perdata saja, tetapi masih mundur ke belakang sampai pada hukum Romawi. Sedangkan, mengenai Undang-Undang Nomor 1 Tahun 1974 hanya dapat dimengerti dengan meneliti sejarah tentang emansipasi wanita Indonesia.

\section{f. Interpretasi Perbandingan Hukum}

Interpretasi ini mengusahakan penyelesaian suatu isu hukum dengan membandingkan berbagai stelsel hokum. Dengan memperbandingkannya hendak dicari kejelasan mengenai suatu ketentuan undang-undang, terutama bagi hukum yang timbul dari perjanjian internasional.

Menurut Lemaire interpretasi perbandingan hukum ini penting, karena dengan pelaksanaan yang seragam direalisasi kesatuan hukum yang melahirkan perjanjian internasional sebagai hukum obyektif (kaidah hukum) untuk beberapa negara ${ }^{42}$. Di luar hukum perjanjian internasional kegunaan metode ini terbatas.

\section{g. Interpretasi Antisipasi}

Interpretasi antisipasi atau Interpretasi futuristik diperlukan untuk menjawab suatu isu hukum dengan mendasarkan pada suatu aturan yang belum berlaku. Dengan lain kata, bahwa interpretasi antisipasi merupakan penjelasan ketentuan undang-undang dengan

\footnotetext{
${ }^{40}$ Ibid., hal. 17.

${ }^{41}$ Soewoto, Ibid., hal. 33.

${ }^{42}$ Sudikno Mertokusumo dan A. Pitlo, Op. Cit., hal. 19.
} 
berpedoman pada undang-undang yang belum mempunyai kekuatan hukum.

\section{h. Interpretasi Teleologis [Teleologische Interpretie]}

Setiap interpretasi pada dasarnya adalah teleologis. Metode ini digunakan jika hakim ingin memahami hukum dalam kaitannya dengan maksud dan tujuan pembuat undang-undang. Ajaran "de rechter is bounche de la loi" mutlak mewajibkan hakim harus memahami maksud dan tujuan pembuat undang-undang. Tujuan hukum dan tujuan pembuat undang-undang berbeda. Tujuan hukum sifatnya umum yang isinya ditentukan ditentukan oleh doktrin hukum. Tujuan pembuat undang-undang sifatnya khusus, dalam arti setiap undang-undang mempunyai tujuan dan politik perundangan sendiri. ${ }^{43}$ Contoh, apakah penyadapan atau penggunaan tenaga listrik untuk kepentingan sendiri yang dilakukan orang lain termasuk pencurian menurut Pasal 362 KUH Pidana (Catatan: seandainya pada waktu undang-undang ini dibuat diasumsikan belum dibayangkan adanya kemungkinan pencurian aliran listrik). Pertanyaan yang kemudian muncul yaitu apakah tenaga listrik itu merupakan barang yang dapat diambil menurut rumusan Pasal 362 KUH Pidana. Kemudian akan ditafsirkan, bahwa tenaga listrik itu ersifat mandiri dan mempunyai nilai tertentu, karena untuk memperolehnya diperlukan biaya dan aliran listrik dapat diberikan orang lain dengan penggantian biaya, dan bahwa Pasal 362 KUH Pidana bertujuan untuk melindungi harta kekayaan orang lain.

\section{Metode Kajian Ilmu Hukum}

Penelitian ilmu hukum menurut Peter M. Marzuki, dilakukan untuk mencari pemecahan atas isu hukum yang timbul. Hasil yang dicapai bukan menolak atau menerima hipotesis, melainkan memberikan preskripsi memgenai apa yang seyogyanya atas itu yang diajukan. ${ }^{44}$ Berdasarkan penjelasan di atas, metode yang dipergunakan dalam mengkaji ilmu hukum juga memiliki perbedaan dengan metode dalam mengkaji ilmu selain ilmu hukum, misalnya ilmu sosial maupun ilmu alamiah menurut Marzuki.

Perbedaan metode kajian terhadap ilmu hukum pada dasarnya, beranjak dari sifat dan karaker ilmu hukum itu sendiri, yaitu sifatnya yang normatif, praktis, terapan dan preskriptif. Mengikuti karakteristik kelimuan tersebut, ilmu hukum selalu berkaitan dengan apa yang seyogianya atau apa yang

\footnotetext{
${ }^{43}$ Soewoto, Op. Cit., hal. 34.
}

44 Peter M. Marzuki, 2001, "Penelitian Hukum", dalam Yuridika Jurnal Hukum Universitas Airlangga Surabaya, Volume 16 No. 1, Maret-April 2001, hal. 1. 
seharusnya. Sekarang yang menjadi pertanyaan dengan karakter tersebut apakah metode ilmiah dapat diterapkan untuk ilmu hukum?

Menurut Webster Dictionary, scientific method adalah:

Principles and procedures for the systematic of knowledge involving the recognition and formulation of a problem, the collection of data through observation and experiment, and the formulation and testing of hypotheses. ${ }^{45}$

Berdasarkan hal tersebut, maka secara umum alur berpikir yang tercakup dalam metode ilmiah dapat dijabarkan dalam beberapa langkah-langkah antara lain: (1) perumusan masalah, (2) penyusunan kerangka berpikir dalam pengajuan hipotesis, (3) perumusan hipotesis, (4) pengujian hipotesis, dan (5) penarikan kesimpulan. ${ }^{46}$

Keseluruhan langkah di atas harus ditempuh agar suatu penelaahan dapat disebut ilmiah walaupun langkah-langkah ini secara konseptual tersusun dalam urutan yang teratur. Di mana langkah yang satu merupakan landasan bagi langkah berikutnya, namun dalam praktek sering terjadi lompatan-lompatan. Hubungan antara langkah yang satu dengan langkah yang lainnya tidak terikat secara statis melainkan dinamis dengan proses pengkajian ilmiah yang tidak semata mengandalkan penalaran melainkan juga imajinasi dan kreativitas. Dengan demikian, bahwa langkah satu bukan saja merupakan landasan bagi langkah beikutnya, namun sekaligus juga sebagai landasan koreksi bagi langkah yang lain. Dengan jalan ini, menurut Bambang Sunggono ${ }^{47}$, diharapkan juga diproseskan pengetahuan yang bersifat konsisten dengan pengetahuan-pengetahuan yang bersifat konsisten dengan pengetahuanpengetahuan sebelumnya serta teruji kebenarannya secara empiris.

Pada awalnya, metode ilmiah hanya digunakan untuk ilmu-ilmu alamiah. Hal ini disebabkan keilmuan tersebut bersifat deskriptif, yaitu mengemukakan apa yang ada berdasarkan fakta empirik. ${ }^{48}$ Menurut Berbard Barber, metode ilmiah tersebut juga dapat diterapkan dalam ilmu-ilmu sosial. Hal ini

45 Peter Mahmud Marzuki, 2006, "Penelitian Hukum", (Jakarta: Kencana Prenada Media Group, 2006), hal. 26. 342.

${ }^{46}$ Jujun S. Suriasumantri, "Filsafat Ilmu”, (Jakarta: Pustaka Sinar Harapan, 1998), hal.

47 Bambang Sunggono, "Metodologi Penelitian Hukum", (Jakarta: RajaGrafindo Persada, 1998), hal. 511.

${ }^{48}$ Sebagaiman diketahui bahwa metode ilmiah secara sistematis pertama kali diusung oleh oleh Francis Bacon, meskipun formulasinya mengalami beberapa penyempurnaan. Secara umum formulasi Bacon ini diterima kalangan ilmuan sejak abad XVII sampai saat ini. Dengan metode ini para ilmuan dalam mencari kebenaran melakukan eksperimen yang tujuannya untuk melakukan observasi secara cermat, teliti, dan mendetail mengenai gejala-gejala yang bersifat alamiah. Oleh sebab itulah awalnya metode ilmiah diperuntukkan bagi ilmu-ilmu alamiah. 
mengingat, bahwa perbedaan antara ilmu-ilmu alamiah dan ilmu-ilmu sosial hanya dalam tingkat perkembangannya bukan pada karakteristiknya. ${ }^{49}$ Berbeda dengan Barber, menurut Edwin W. Patterson, menawarkan penggunaan metode ilmiah di dalam penelitian hukum. Akan tetapi dalam perbincangan selanjutnya ia terjebak ke dalam masalah perilaku dan efektivitas. Ia tidak menyentuh hal-hal yang bersifat preskriptif. ${ }^{50}$

Berdasarkan paparan tersebut dapat disimpulkan, bahwa metode ilmiah, yaitu logico-hypotetico-verivicative hanya berlaku untuk keilmuan yang bersifat deskriptif, yaitu dalam kerangka menelaskan hubungan sebab-akibat antara dua hal. Menurut hemat penulis sifat keilmuan hukum adalah preskriptif. Dengan demikian, metode dan prosedur penelitian dalam ilmu-ilmu alamiah dan ilmu-ilmu sosial tidak dapat diterapkan untuk ilmu hukum.

Berkaitan dengan permasalahan tersebut, menurut Philipus M. Hadjon, ilmuwan hukum haruslah menegaskan: (1) dengan cara apakah yang pasti, dia membangun teorinya; (2) haruslah menyajikan langkah-langkahnya sehingga pihak lain dapat mengontrol hasil teorinya (controleerbaar); dan (3) harus mempertanggungjawabkan kenapa memilih cara yang demikian. ${ }^{51}$

Apa yang dikemukan oleh Philipus M. Hadjon cukup beralasan. H. J. van Eikema Hommes menyatakan, bahwa setiap ilmu pengetahuan memiliki metodenya sendiri. ${ }^{52}$ Dengan demikian menurut penulis, dalam pemilihan metode untuk mengkaji ilmu hukum harus merujuk pada beberapa hal dan sekaligus sebagai pembatas, yaitu: perumusan masalah, obyek yang diteliti dan tradisi keilmuan hukum itu sendiri. Hal ini merujuk pada hasil dari suatu penelitian hukum tersebut, yaitu pada dasarnya adalah argumentasi hukum. Langkah demikian diharapkan pada akhirnya dapat merumuskan suatu teori. ${ }^{53}$

49 Peter Mahmud Marzuki, Op. Cit., hal. 27-28. Terdapat lima disiplin yang dapat dikatakan benar-benar ilmu sosial, yaitu Ilmu Ekonomi, Ilmu Politik, Psikologi, Sosiologi, dan Anthropologi. Hal ini disebabkan kelima disiplin tersebut mempunyai obyek perilaku masyarakat. Selain itu juga masih terbuka disiplin lain untuk dapat dikatakan sebagai ilmu sosial, yaitu sejarah.

${ }^{50}$ Ibid., hal. 28.

${ }^{51}$ Philipus M. Hadjon, 1994, "Pengkajian ...., , Op. Cit., hal. 7.

${ }^{52}$ Peter M. Marzuki, 2003, "Penelitian Hukum", Makalah. Lokakarya Penelitian Hukum Normatif di Jurusan Hukum Pidana Fakultas Hukum Universitas Jember tanggal 4 Oktober 2003, hal. 1.

${ }^{53}$ Menurut Jan Gejssels dan Mark van Hoecke, bahwa ilmu hukum pada dasarnya mempunyai dua aspek, yaitu aspek praktis yang berupa dogmatik hukum dan aspek teoritis berupa teori hukum. Oleh sebab itu, penelitian hukum dapat dibedakan menjadi penelitian untuk keperluan praktis dan penelitian untuk kajian akademis. Lihat Ibid. 


\section{Kesimpulan}

Berdasarkan uraian di atas, maka dapat disimpulkan kembali pokokpokok pikiran sebagai berikut:

1. Ilmu hukum diterima sebagai ilmu dengan tetap menghormati karakter keilmuan ilmu hukum yang merupakan kepribadian ilmu hukum, yaitu normatif, terapan dan preskriptif. Dengan karakter yang khas tersebut ilmu hukum merupakan sui generis;

2. Menetapkan metode penelitian hukum dalam cakupan yang lebih luas (pengkajian ilmu hukum), seharusnya beranjak dari hakikat keilmuan hukum, yang meliputi 2 (dua) aspek pendekatan, yang dapat dilakukan untuk menjelaskan keilmuan hukum dan dengan sendiriya membawa konsekuensi pada metode kajiannya, yaitu: pendekatan dari sudut falsafah ilmu, dan pendekatan dari sudut pandang teori hukum. 


\section{Daftar Pustaka}

Bruggink, J.J.H. Refleksi Tentang Hukum, Terjemahan Bernard Arief Sidharta, Bandung: Citra Aditya Bhakti, 1999.

Hadjon, Philipus M. "Pengkajian Ilmu Hukum Dogmatik (Normatif)", dalam Yuridika Jurnal Hukum Universitas Airlangga Surabaya, No. 6 Tahun IX, November - Desember 1994. dan Tatiek Sri Djatmiati. Argumentasi Hukum, Yogyakarta: Gadjah Mada University Press, 2005.

Marzuki, Peter M. Penelitian Hukum, Jakarta: Kencana Prenada Media Group, 2006. , 2001, "Penelitian Hukum", dalam Yuridika Jurnal Hukum Universitas Airlangga Surabaya, Volume 16 No. 1, Maret-April 2001. , 2003, "Penelitian Hukum", Makalah. Lokakarya Penelitian Hukum Normatif di Jurusan Hukum Pidana Fakultas Hukum Universitas Jember tanggal 4 Oktober 2003.

Mertokusumo, Sudikno. dan Pitlo, A. Bab-Bab Tentang Penemuan Hukum, Bandung: Aditya Citra Bhakti, 1993.

Muhjad, M. Hadin., dkk. Peran Filsafat Ilmu dalam Ilmu Hukum: Kajian Teoritis dan Praktis, Surabaya: Unesa University Press, 2003.

Sidharta, Bernard Arief. Refleksi Tentang Struktur Ilmu Hukum, Bandung: Mandar Maju, 2000.

Soewoto, "Metode Interpretasi Hukum Terhadap Konstitusi" dalam Yuridika Jurnal Hukum Universitas Airlangga Surabaya, No. 1 Tahun V, Januari Pebruari 1990.

Sri Winarsi, "Hukum Otonomi Daerah dalam Perspektif Filsafat Ilmu" dalam Jurnal Konstitusi LKK Universitas Airlangga Volume I Nomor 1, November 2008.

Sunggono, Bambang. Metodologi Penelitian Hukum, Jakarta: RajaGrafindo Persada, 1998.

Suriasumantri, Jujun S. Filsafat Ilmu, Jakarta: Pustaka Sinar Harapan, 1998.

Trianto dan Tutik, Titik Triwulan. "Ilmu Hukum sebagai Sui Generis: Sebuah Pengantar", dalam Trianto dan Titik Triwulan Tutik (eds.), Bunga Rampai Ilmu Hukum, Jakarta: Prestasi Pustaka, 2007.

Tutik, Titik Triwulan. Pengantar Ilmu Hukum, Jakarta: Prestasi Pustaka, 2006. 